\title{
MODERNITAS DAN GLOBALISASI: TANTANGAN BAGI PERADABAN ISLAM
}

\section{Muhammad Rusydy}

\author{
Fakultas Ushuluddin dan Studi Agama UIN STS Jambi \\ email:drmuhammadrusydi@gmail.com
}

\begin{abstract}
This paper aims to explain the globalization and modernity inpact problem for Islamic civilization. Rennassaince that has been developing in west and has been giving inpact not only for progressing science and technology but also for modernity acceleration in a veriety of life field. But, the progress not for Islam because it has been facing the internal problem such as stupidity and destitution. So that, the conditions have given inpact for Islam that has been more inferior than west. The globalization and modernity moslem civilization was changed by the western civilization.

Makalah ini bertujuan untuk membahas tentang dampak modernitas dan globalisasi bagi peradaban Islam. Renaissans yang membawa kepada kemajuan di Barat bukan hanya membawa kemajuan dalam bidang ilmu pengetahuan dan teknologi tetapi juga memunculkan berbagai kemudahan dalam berbagai bidang kehidupan. Maka muncul modernitas dan globalisasi. Namun modernitas dan globalisasi ini tidak banyak menguntungkan Islam dan kaum muslim karena membawa ekses negatif dalam kalangan internal mereka. Bahkan, modernitas dan globalisasi ini menjadi tantangan bagi peradaban Islam dan kaum muslim.
\end{abstract}

Keywords: Modernitas, Globalisasi, Peradaban Islam, Sekularisme, Westernisme

\section{Pendahuluan}

Dunia Islam membentang dari Atlantik hingga Pasific, dari India Selatan dan jantung Afrika sampai Siberia, Albania, dan Bosnia. Islam juga terasa kehadirannya di beberapa bagian Eropa, Amerika, Afrika Tengah dan Selatan. Jumlah umat Islam lebih dari satu milyar yang mendiami wilayah-wilayah muslim dan mereka minoritas di beberapa negara. Agama Islam masih hidup dan kuat,

$$
\text { TAJDID Vol. 17, No. 1, Januari - Juni } 2018 \mid 91
$$


namun peradaban Islam terasa telah lemah dalam beberapa abad terakhir. Ini sebagai akibat dari tantangan berupa kekuatan materi, pemikiran-pemikiran asing, dan modernitas.

Struktur sosial dunia Islam termasuk lembaga-lembaga politik dan ekonomi juga menghadapi tantangan berat, sehingga terjadi ketegangan dan perubahan dalam tubuh struktur sosial dunia Islam. Akibatnya peradaban Islam semakin surut bahkan tersingkir dari berbagai arah secara luar biasa besarnya dan belum pernah tejadi dalam sejarah Islam sebelumnya. Tantangan terhadap peradaban Islam dimulai sejak masa eksplorasi yang dikenal dengan renaissans dalam sejarah Eropa sekitar abad ke 16 dan ke 17 M. Pada masa itu Portugis, Spanyol, dan Belanda; segera diikuti oleh Inggris kemudian Prancis mencoba merebut wilayah-wilayah Islam. Rute pelayaran di Laut tengah dan India yang mempunyai nilai ekonomi tinggi bagi dunia Islam diambil alih oleh kekuatan laut Eropa. Berangsur-angsur kekuatan ini mulai melakukan penetrasi ke wilayah-wilayah utama dunia Islam.

Selama periode ini, sebagian Asia Tenggara yang menjadi wilayah penting dunia Islam, dijajah, begitu pula halnya India dan Afrika. Sementara dengan tumbuhnya kekuatan Rusia sebagai sebuah bangsa, kaum muslim di wilayah utara misalnya Kaspia dan Asia Tengah mulai merasa ditekan oleh kekuatan baru itu. Kerajaan Turki, Persia, dan Afrika Utara tidak disentuh, tapi pada abad ke 18 M., sebagai jantung dunia Islam, mereka mulai merasa diancam oleh pelanggaran-pelanggaran Barat. Pada akhir abad ke 20 M., ketika seluruh dunia Islam memperoleh kebebasan secara fisik, kaum muslim di wilayah-wilayah itu justeru mengalami depresi oleh arus globalisasi yang lebih kompleks.

Peristiwa yang membangkitkan kesadaran dunia Islam terhadap ancaman bahaya dan tantangan dari Barat adalah invasi Mesir oleh Napoleon pada tahun 1798 M. Peristiwa itu menjadi saksi bagi transformasi kesadaran dunai Islam dan peerubahan sikap mereka terhadap Barat. Merupakan hal yang aneh bahwa

\section{2 | TAJDID vol. 17, No. 1, Januari - Juni 2018}


hampir selama tiga abad, ketika Barat semakin kuat secara militer dan ekonomi, dan di sana terjadi renaissans serta revolusi ilmu pengetahuan dan teknologi, dunia Islam tidak memperlihatkan sedikit minat untuk memperhatikan apa yang sedang terjadi di Barat, sampai akhirnya terjadi invasi oleh Napoleon terhadap Mesir.

\section{Sekilas Tentang Modernitas dan Globalisasi}

Ada pendapat bahwa zaman sekarang tidak tepat lagi disebut sebagai zaman modern. Ini disebabkan karena faktor-faktor modernitas telah terlampaui dengan tercapainya lompatan kemajuan di bidang ilmu pengetahuan dan teknologi khususnya elektronik, komunikasi, dan informasi. Karena itu, ada yang menyebut zaman sekarang sebagai zaman pos modernisme dan kontemporer, maksudnya ialah zaman kekinian. Memang sulit untuk membatasi zaman modern dalam suatu rentang waktu tertentu. Robert N. Bellah sendiri telah menyebut masyarakat muslim pada zaman Nabi Muhammad telah memasuki zaman modern karena Nabi Muhammad telah membangun masyarakat muslim dengan lompatan jauh ke depan dalam kecanggihan sosial dan kapasitas politik. Kecanggilan sosial dan struktur politik kaum muslim klasik tersebut telah mengandung ciri modernitas misalnya inklusivisme, egalitar, demokratis, dan partisipatif, suatu kemajuan sistem sosial kemasyarakatan yang melampaui zamannya. ${ }^{1}$

Jauh sebelum zaman Islam, ketika terjadi peralihan dari zaman Romawi lama ke periode Masehi (490-500), masyarakat Kristen telah mengenal dan memakai istilah modernitas. ${ }^{2}$ Namun demikian, istilah modernitas baru menjadi populer pada akhir abad ke 15 M. Pada masa ini orang-orang Barat menemukan ilmu

${ }^{1}$ Robert N. Bellah, "Islamic Traditions and Problems Of Modernization," dalam Robert N. Bellah, ed., Beyond Belief, (New york: Harper \&Row, 1976), 150.

2 Arkoun, "Introduction, Common Etudier," dalam Pour une Critiquede la Raison Islamique, (Paris: Maisonneuve et Larose, 1987), 49. 
pengetahuan dan teknologi sekaligus meninggalkan dominasi Gereja. ${ }^{3}$ Pada abad ke 14 M., Barat mengalami krisis sampai pertengahan abad ke $15 \mathrm{M}$. Pada abad ke 15 dan $16 \mathrm{M}$., muncul gerakan renaissans. Pada masa ini, kata modern telah muncul sebagai sebutan bagi kaum Occamist (pengikut William dari Ockham). ${ }^{4}$

Selanjutnya pada abad ke 16 sampai ke 18 M., di Barat terjadi transformasi budaya yang membawa masyarakat Barat menuju modernitas. Kemudian yang dianggap sebagai pahlawan modernitas adalah Galileo Galilei (15654-1642 M.). Sejak masa itu, para intelektual dan ilmuan melakukan usaha rasionalitas yang merupakan landasan modernitas. ${ }^{5}$ Sebelumnya, Nicolaus Copernicus (1473-1543 M.), telah menemukan teori etnosentris, bahwa matahari adalah pusat jagad raya. Bumi merupakan salah satu planet dalam jagad raya ini yang mempunyai dua macam gerak, yakni rotasi (perputaran sehari-hari pada porosnya) dan evolusi (perputaran tahunan mengelilingi matahari). Teori ini mementahkan teori geosentris dari Ptolemeus yang menjadi dogma Gereja, berabad-abad sebelumnya, bahwa pusat jagad raya adalah bumi. Kemudian Johannes Kepler (1571-1630 M.) mengembangkan teori Copernicus tersebut. Selanjutnya penemuan teori yang mengguncang dogma Gereka itu diikuti oleh penemuan lainnya misalnya, gravitasi bumi oleh Issac Newton (1642-1727 M.) yang memengaruhi cita-cita pencerahan pada abad ke $18 \mathrm{M}^{6}$

Perkembangan-perkembangan di atas mencapai puncaknya pada zaman dua peristiwa yang lebih kurang terjadi secara

3 Arnold Toynbee, A Study Of History, ringkasan DD. Somervelle, (Oxford: Oxford University Press, 1957), 148.

${ }^{4}$ Bertrand Rusell, History Of Western Philosophy, (London: George Allen \& Unwin Ltd., 1974), 500.

${ }^{5}$ David E. Apter, The Politics Of Modernization, (Chicago: The University of Chicago Press, 1966), 43.

${ }^{6}$ Bertrand Rusell, History Of Western Philosophy, (London: George Allen \& Unwin Ltd., 1974), 500. 
simultan, yaitu revolusi industri di Inggris dan revolusi sosial di Prancis (1789-1799 M.). Revolusi industri di Inggris kemudian menyebabkan munculnya kemajuan dalam bidang ilmu pengetahuan dan teknologi, sehingga gelombang teknologi ini dianggap sebagai kelombang kedua peradaban manusia. ${ }^{7}$ Sementara revolusi sosial di Prancis menimbulkan bangunan norma-norma baru dalam hubungan antar umat manusia. Beberapa tahun sebelum adanya kedua revolusi itu, Jean Jacques Rousseau (1712-1778 M.) sudah menggunakan kata modern dalam arti nasionalisme, rasionalisme, sekularisme, industrialisasi, dan penggandaan keuntungan sebagaimana yang dikenal pada zaman sekarang. ${ }^{8}$

Pada akhir abad ke 20 M., kemajuan ilmu pengetahuan dan teknologi mengalami lompatan spektakuler yang ditandai oleh kemajuan di bidang teknologi komunikasi dan informasi. Oleh karena itu, para ahli futurolog menyebut zaman sekarang sebagai era globalisasi atau era globalisasi informasi. Ditandai oleh era ini, maka menurut Alvin Toffler, peradaban manusia memasuki gelombang ketiga yaitu gelombang informatika. Dua gelombang peradaban manusia sebelumnya adalah pertanian dan industri. Pada era ini, sumber kekuasaan dan kekuatan manusia tergantung pada penguasaan informasi, bukan lagi pada penguasaan sumber daya alam dan hasil produksi sebagaimana pada era pertanian dan industri. Dalam era gelombang informatika ini pula lebih dari 60 persen pekerjaan bergerak dalam bidang jasa dan informasi. ${ }^{9}$

Gejala era informatika mulai muncul di Amerika Serikat sekitar pada tahun 1960 M. Setelah melalui penemuan-penemuan baru dalam teknologi komunikasi dan informasi maka kemudian lahir revolusi komunikasi. Akibatnya gelombang era informatika

${ }^{7}$ Alvin Toffler, The Third Wave, (Toronto: Bantam Book Inc., 1984), 40.

${ }^{8}$ Harvey Cox, Religion In The Secuar City, (New York: Simon and Schuster, 1984), 181.

9 Azyumardi Azra, Konteks Berteologi di Indonesia Pengalaman Islam, Jakarta: Paramadina, 1999), 203.

TAJDID Vol. 17, No. 1, Januari - Juni $2018 \mid 95$ 
melanda hampir seluruh dunia termasuk dunia Islam. Gelombang informasi yang menciptakan globalisasi tidak dapat dibendung. ${ }^{10}$ Globalisasi telah melampaui batas-batas etnis, bangsa, dan negara sehingga dunia yang luas bagaikan suatu desa yang disebut dengan istilah "Desa Buana"."

Dalam rangka revolusi komunikasi maka muncul peralatanperalatan teknologi komunikasi yang canggih misalnya tv, komputer networks (internet), video, cd, telepon global (ponsel), dan sebagainya. Melalui instrumen-instrumen ini, peristiwa dan budaya atau peradaban yang muncul dan terjadi di suatu belahan dunia dapat disaksikan secara langsung di belahan dunia lain. Semua kejadian itu disaksikan tanpa filter oleh semua orang tanpa batasan gender, umur, pendidikan, dan profesi.

Kemajuan ilmu pengetahuan dan teknologi yang merupakan anak kandung modernitas pada abad ke 19 M., dan era globalisasi informasi pada akhir abad ke 20 M., telah menyerbu dunia Islam. Kalau ilmu pengetahuan dan teknologi yang dikenal dengan masa modern dalam sejarah Islam masuk ke dunia Islam melalui pintu pendudukan Napoleon Bonaparte di Mesir, maka teknologi komunikasi dan informasi yang bermuara pada globalisasi menyerbu dunia Islam melalui berbagai pintu. Hal-hal ini selanjutnya menimbulkan tantangan-tantangan baru bagi peradaban Islam.

\section{Tantangan bagi Peradaban Islam}

Pengertian peradaban sering dikacaukan dengan kebudayaan. Memang dalam beberapa pengertian terkadang pengertian peradaban lebih luas dari pada kebudayaan, namun sebaliknya terkadang pengertian kebudayaan lebih luas dari pada peradaban,

10 Azyumardi Azra, Konteks Berteologi di Indonesia Pengalaman Islam, 204.

11 Nurcholish Madjid, "Mencari Akar-akar Islam bagi Pluralisme Modern Pengalaman Indonesia" dalam Mark R. Woodward, Jalan Baru Islam Memetakan Paradigma Mutakbir Islam Indonesia, terj. Ihsan Ali Fauzi, (Bandung: Mizan, 1998), 37.

96 | TAJDID vol. 17, No. 1, Januari - Juni 2018 
tergantung dari sudut pandang mana melihatnya, apakah dari sudut pandang sejarah; sosiologi; antropologi; atau psikologi.

Salah satu pengertian peradaban misalnya bahwa peradaban adalah entitas kebudayaan. ${ }^{12}$ Dalam pengertian ini, maka peradaban lebih luas dari pada kebudayaan karena yang dimaksud peradaban ialah kumpulan beberapa atau berbagai kebudayaan. Kebudayaan-kebudayaan beberapa etnis bisa menjadi suatu peradaban bangsa, dan kebudayaan-kebudayaan berbagai bangsa bisa menjadi peradaban dunia. Sementara salah satu pengertian kebudayaan, bahwa kebudayaan ialah hasil karya manusia. ${ }^{13}$ Menurut pengertian ini maka kebudayaan mencakup peradaban karena apapun hasil karya manusia baik positif maupun negatif merupakan kebudayaan. Termasuk hasil karya manusia yang bersifat positif ialah peradaban.

Peradaban di sini ialah dalam pengertian kebudayaan sebagaimana menurut Lewis A. Coser dan Bernard Rosenberg, bahwa kebudayaan adalah peradaban atau dengan kata lain peradaban adalah kebudayaan. ${ }^{14}$ Dalam pengertian ini maka peradaban adalah hasil perkembangan dan kemajuan manusia yang meliputi sastra, seni, ekonomi, teknik, sosial, ide, pemikiran, dan nilai. ${ }^{15}$ Menurut Nurcholish Madjid bahwa peradaban merupakan tali hubungan antara manusia dengan Tuhan yang diterjemahkan oleh manusia secara nyata menjadi tali hubungan dengan sesama manusia. Dalam pengertian selanjutnya Nurcholish Madjid menyatakan bahwa peradaban Islam adalah peradaban kaum muslim, atau dengan kata lain peradaban Islam ialah hasil ciptaan

12 Samuel P. Huntington, Benturan Antar Peradaban dan Masa Depan Politik Dunia, terj. M. Sadar ismail, (Yogyakarta: Qalam, 2002), 39.

${ }^{13}$ Edward B. Tylor, Encyclopedia Americana, vol. 8, (New York: 1971), 108.

${ }^{14}$ Lewis A. Coser dan Bernard Rosenberg, ed., Sociology Theory A Book Of Reading, (Landon: The Macmillan Company, 1969), 20.

15 Soerhanto Poespowardojo, Strategi Kebudayaan Suatu Pendekatan Filosofis, (Jakarta: Gramedia, 1989), 220. 
kaum muslim yang mempunyai komitmen terhadap Islam. ${ }^{16}$ Peradaban merupakan fungsi kekhalifahan manusia dan karena itu, peradaban Islam merupakan fungsi kekhalifahan kaum muslim di dunia. $^{17}$

Berangkat dari beberapa pengertian tersebut di atas maka dapat dikatakan bahwa peradaban Islam adalah hasil perkembangan dan kemajuan kaum muslim yang meliputi nilainilai keislaman, peranata-peranata keislaman, adat tradisi, idepemikiran, dan tugas-tugas kemanusiaan. Peradaban inilah yang menghadapi tantangan berupa rasionalisme, sekularisme, nasionalisme, toleransi, pluralisme, dan transformasi budaya yang merupakan nilai-nilai modernitas dan globalisasi.

Masuknya modernitas ke dunia Islam, sebagaimana disinggung di atas, melalui proses yang disebut invasi. Untuk pertama kalinya hal itu terjadi melalui peristiwa sejarah yang sudah populer yaitu ekspedisi Napoleon Bonaparte ke Mesir (1798-1801 M.). Semenjak itu modernitas tidak hanya menimbulkan implikasi positif di dunia Islam, tetapi juga sejumlah problem dan tantangan, apalagi sudah sedemikian banyaknya kemajuan Barat yang tidak terpikirkan oleh kaum muslim. Tantangan itu juga akan bertambah banyak seiring dengan pesatnya kemajuan ilmu pengetahuan dan teknologi di Barat. Barat sendiri yang merupakan tempat persemaian modernitas kini sedang mempertanyakan pada dirinya sendiri tentang dampak positif dan negatif dari pengalaman yang dilaluinya. Di antara konsep-konsep yang dipertanyakan itu adalah nominalisme yang tercermin dalam pemikiran Thomas Hobbes (1588-1679 M.), kedaulatan subjek yang ditegaskan oleh Descartes, historisisme; teori relativitas; sekularisme; rasionalisme; positivisme yang dicetuskan oleh Auguste Comte, materialisme

${ }^{16}$ Nurcholish Madjid, Islam Doktrin dan Peradaban, (Jakarta: Paramadina, 2000), xiv.

${ }^{17}$ Nurcholish Madjid, Islam Doktrin dan Peradaban, xiv. 
dialektis yang digagas oleh Karl Marx, dan lain sebagainya. ${ }^{18}$ Ini berarti bahwa modernitas telah menimbulkan sejumlah persoalan yang tidak hanya dihadapi oleh kaum muslim, tetapi juga dihadapi oleh Barat sendiri, meskipun problem yang dihadapi oleh kaum muslim jauh lebih berat.

Problem yang ditimbulkan oleh modernitas di lingkungan kaum muslim sendiri terasa berat karena sejumlah faktor misalnya adanya tekanan demografis yang menimpa kaum muslim selama abad ke 19 dan awal abad ke 20 M., despotisme lembaga politik, dan ekses ideologi luar seperti liberalisme, sekularisme, komunisme, dan lain sebagainya yang tidak sesuai dengan kebutuhan kaun muslim. Dalam serbuan perubahan yang dicapai oleh Barat, setelah dunia Islam lepas dari cengkeraman imperialisme, pemikiran Islam tidak memiliki sistem, sumber daya, atau kekuatan intelektual. Semuanya menumpuk di Barat dengan nama modernitas. Sehingga di tengah kaum muslim muncul pelbagai tindakan kekerasan sebagai wacana beberapa gerakan Islam kontemporer, dan ketercerabutan para petani dan penduduk kampung dari akar-akar budaya mereka. Ini menyebabkan mereka menjadi kaum proletar yang melakukan pekerjaan kasar di kotakota. Sementara di pihak lain adanya monopoli kekuasaan di tangan satu orang penguasa, partai, atau raja. ${ }^{19}$ Semua itu terakumulasi menjadi penyakit. Kemudian menyebabkan munculnya berbagai perkembangan dan reaksi yang tidak terkendali.

Dalam konteks batasan, paling tidak ada tiga pilar yang menjadi soko guru modernitas yaitu ilmu pengetahuan yang berujung pada rasionalisme, negara bangsa yang berujung pada nasionalisme, dan penyepelean peran agama yang berujung pada

18 Arkoun, "Introduction, Common Etudier," dalam Pour une Critiquede la Raison Islamique, 59-60.

19 Arkoun, "Introduction, Common Etudier," dalam Pour une Critiquede la Raison Islamique, 129. 
sekularisme. ${ }^{20}$ Ketiga masalah inilah yang menjadi problem sekaligus tantangan bagi kaum muslim menyambut datangnya modernitas sejak abad ke 19 M., dan globalisasi informasi sejak penghujung abad ke 20, di samping problem turunan lainnya semisal toleransi, pluralisme, dan transformasi budaya.

Dengan adanya keterputusan intelektual dan peradaban di kalangan kaum muslim, maka intelektualitas merupakan problem pertama yang menjadi tantangan kaum muslim dalam kaitannya dengan problem rasionalitas. Muncul pertanyaan intelektualitas misalnya bagaimana unsur manusia khususnya rasio yang dimilikinya berperan dalam meraih kebenaran di luar wahyu. Masalah wahyu ini memang rumit, namun penting terutama bagi mereka yang ingin mengkajinya dengan cakrawala luas melampaui ortodoksi. Membahas soal wahyu menurut al-Qur'an dan tradisi Islam tidak semudah membahas wahyu dalam konteks Kristen. Jika ada isu baru yang dihadapkan kepada al-Qur'an, yang muncul adalah suara-suara emosional. Ini berbeda dengan tradisi Kristen.

Masalah intelektualitas lainnya adalah mengenai penerimaan ilmu pengetahuan Barat. Dalam hal ini, jika sejarah klasik Islam dianalisis, maka akan dijumpai fatwa bahwa filsafat dan ilmu pengetahuan Yunani telah diserap oleh dunia Islam sejak abad ke 8 atau ke 9 M. Namun sejak akhir abad ke 9 M., muncul usahausaha menentang penyebaran ilmu pengetahuan rasional yang bersinggungan dengan ilmu-imu keagamaan "tradisional". Misalnya Ibn Quthaibah (w. 889 M.) yang menyerang pemikir yang terpengaruh oleh pemikiran Aristoteles. Jangan heran jika sejak abad ke 16 M., pemikiran Islam berada di pinggiran pemikiran spekulatif Barat. Sejak abad ke 19 M., yang dilakukan oleh kaum muslim hanya berapologi dengan membanggakan diri atas kecemerlangan masa lalu sambil menolak Barat. ${ }^{21}$

${ }^{20}$ Harvey Cox, Religion In The Secuar City, 183.

21 Arkoun, "Introduction, Common Etudier," dalam Pour une Critiquede la Raison Islamique, 42.

100 | TAJDID Vol. 17, No. 1, Januari - Juni 2018 
Lalu bagaimana menghadapi ilmu pengetahuan Barat yang berkembang pesat, apakah harus diterima begitu saja, ditolak, atau diseleksi. Sebagai contoh, bagaimana dengan metode kritik sejarah. Islam adalah agama yang bersifat benar karena bersumber dari wahyu Tuhan, namun disisi lain terdapat ilmu sejarah yang lahir dari intelektualitas manusia dan berkembang begitu rupa. Penghadapan antara keduanya belum pernah dikaji dalam tradisi pemikiran Islam klasik. Pada masa sekarang pun pemikiran Islam kurang memperhatikan dialektika lama yang menghubungkan antara wahyu, kebenaran, dan sejarah.

Masalah lain yang juga penting dalam kerangka modernitas adalah sekularisme, yang mana sekularisme merupakan nilai modernitas itu sendiri. Dalam kaitannya dengan ini, Robert N. Bellah menyatakan bahwa krisis spiritual yang menjadi problem modernitas akan mengantarkan manusia untuk menolak keyakinan, moralitas, dan agama. Dengan demikian akan terjadi sekularisasi yang ujungnya bermuara pada sekularisme. ${ }^{22}$

Di Barat terdapat pemikiran bahwa kaum muslim harus menolak sekularisme, karena Islam dan sekularisme bagaikan air dan minyak, dua hal yang tidak dapat bersatu. Pemikiran yang dogmatis ini terutama terdapat di kalangan kaum orientalis dan islamolog. Padahal pada awalnya sekularisme, baik di Barat maupun di dunia Islam khususnya kasus Turki, merupakan masalah politik. Sebelum renaissans di Barat, sebagai akibat dari pengaruh faham Averroisme dari dunia Islam, bahwa agama (Islam) tidak bertentangan dengan ilmu pengetahuan dan teknologi dan agama tidak menghambat kemajuan, maka muncul upaya untuk menafsirkan kembali ajaran agama Kristen supaya sesuai dengan kemajuan ilmu pengetahuan dan teknologi. Namun tidak mudah dilakukan karena ada dogma bahwa ajaran agama Kristen tidak boleh ditafsirkan, sehingga terjadi gap antara perkembangan

22 Robert N. Bellah, "Islamic Traditions and Problems Of Modernization,” dalam Robert N. Bellah, ed., Beyond Belief, 28.

TAJDID Vol. 17, No. 1, Januari - Juni 2018|101 
zaman dan ajaran agama Kristen. Akibatnya muncul anggapan bahwa agama Kristen bertentangan dengan ilmu pengetahuan dan teknologi serta menghambat kemajuan. Karena itu, terjadi gerakan kaum intelektual untuk meninggalkan agama Kristen (pemisahan antara agama dan politik) agar supaya tetap dapat meraih kemajuan ilmu pengetahuan dan teknologi serta dapat menyesuaikan diri dengan perkembangan zaman. Selanjutnya hal ini berkembang menjadi pemisahan antara urusan agma yang bersifat pribadi dan urusan keduniaan. Maka terjadilah sekularisasi. Proses sekularisasi ini berkembang menjadi sekularisme di Barat. Begitu pula di Turki, ketika terjadi proses pemisahan antara urusan agama dan politik, maka terjadi sekularisme. Kalau sekularisme didudukkan secara proporsional maka sekularisme, sebagaimana dalam pandangan Arkoun, sudah terdapat dalam al-Qur'an dan pengalaman masyarakat Nabi Muhammad di Madinah. ${ }^{23}$

Selanjutnya, berkenaaan dengan politik, problem modernitas yang tidak kalah pentingnya adalah masalah nasionalisme. Nasionalisme yang menghasilkan berdirinya negara bangsa menyebabkan terkotak-kotaknya kehidupan berbangsa sebatas lingkup wilayah atau negara. Kehidupan ini akan memunculkan rasa fanatisme golongan dan kebangsaan. Apakah kehidupan semacam ini sejalan dengan konsep persaudaraan (ukhuwwab) dan toleransi (tasâmub) dalam Islam yang tidak mengenal batas etnis dan wilayah. Sama halnya dengan sekularisme, nasionalisme akan menjadi masalah bagi kehidupan keagamaan. Kemudian ada pandangan bahwa Islam dan politik tidak dapat dipisahkan. Pendapat ini menggiring kepada suatu persepsi bahwa Islam membutuhkan suatu negara tersendiri yaitu negara Islam. Negara ini berfungsi untuk menjaga terealisasinya ajaran-ajaran Islam. Padahal ide negara Islam, secara tersirat sering dimotivasi oleh kepentingan material kaum muslim. Misalnya kasus berdirinya

23 Arkoun, "Introduction, Common Etudier," dalam Pour une Critiquede la Raison Islamique, 69.

102 | TAJDID Vol. 17, No. 1, Januari - Juni 2018 
negara Islam Pakistan, secara tidak langsung dimaksudkan untuk menjaga kepentingan material kaum muslim dari mayoritas Hindu di India. Jadi alasannya nasionalistis dan juga bersifat sekular, bukan agamis.

Tantangan lainnya dalam tataran modernitas dan globalisasi adalah toleransi dan pluralisme. Dua hal ini merupakan nilai-nilai modernitas, karena itu baru bagi Islam dan kaum muslim, namun sebenarnya sudah dijumpai dalam kehidupan masyarakat Nabi Muhammad di Madinah. Waktu itu, berdasarkan Piagam madinah, kaum muslim menganggap dirinya satu bangsa dengan kaum Yahudi dan Kristen, dan bahwa mereka memiliki hak dan kewajiban yang sama. Sikap kaum muslim terhadap kaum Yahudi dan Kristen ini merupakan landasan bagi konsep Islam unik mengenai para ahli Kitab. ${ }^{24}$

Sebuah sumber Barat mengenai Islam mengatakan, kenyataan bahwa Islam yang bersumber dari wahyu menyebut wahyu-wahyu yang lain sebagai absah adalah sebuah kejadian luar biasa dalam sejarah agama-agama. Meskipun demikian, bagi Nurcholish Madjid, adalah berlebihan untuk berharap bahwa seseorang akan memandang agama yang lain sama benarnya dengan agamanya sendiri. Dalam kepercayaan aktual sebagian besar kaum muslim, bahwa agama Kristen dan agama lainnya sudah kehilangan kebenarannya. Dalam kepercayaan kaum muslim bahwa orangorang Kristen apalagi penganut agama lainnya tidak akan masuk surga. $^{25}$

Penilaian ini benar berkenaan dengan bagaimana sebagian besar kaum muslim dan pemeluk agama-agama lainnya memandang gagasan toleransi beragama dan pluralisme dalam pengertian modern. Mereka belum pernah mengalami upaya

${ }^{24}$ Nurcholish Madjid, Nurcholish Madjid, "Mencari Akar-akar Islam bagi Pluralisme Modern Pengalaman Indonesia", 99.

${ }_{25}$ Nurcholish Madjid, Nurcholish Madjid, "Mencari Akar-akar Islam bagi Pluralisme Modern Pengalaman Indonesia", 99.

$$
\text { TAJDID vol. 17, No. 1, Januari - Juni 2018 | } 103
$$


mewujudkan gagasan toleransi dan pluralisme dalam realitas kehidupan. Bagi kaum muslim dan kaum Kristen, toleransi adalah kebajikan dan nilai baru. Dalam sejarah kedua komunitas ini, toleransi tidak dipandang sebagai sesuatu yang bernilai, dan intoleransi juga tidak dikecam. Sampai masa modern atau kontemporer, Barat yang Kristen itu pun tidak menghargai atau mempraktekkan toleransi, dan mereka tidak mengecam ketiadaan toleransi di tempat lain. Tuduhan intoleran pihak lain yang sering ditujukan kepada kaum muslim ialah bahwa ajaran Islam itu palsu. $^{26}$

Sebagian episode hubungan antara kaum muslim dan non muslim dalam sejarah Islam klasik, tidak ditandai oleh suatu hubungan toleransi. Banyak contoh yang dapat disebut untuk menunjukkan intoleransi kaum muslim terhadap pemeluk agama lain. Banyak peristiwa di mana penguasa muslim mengambil langkah-langkah keras untuk meredam kebebasan dan kreativitas intelektual kaum muslim sendiri. Ada pula kasusnya yang hampir sama dengan inkuisis, praktek pemaksaan agama di dunia Kristen abad pertengahan. Penindasan seperti ini tidak saja dilakukan oleh kaum muslim yang konservatif terhadap yang liberal, tetapi juga oleh yang liberal terhadap yang konservatif. ${ }^{27}$ Jadi, toleransi dan pluralisme yang merupakan nilai modernitas dan keharusan globalisasi adalah suatu tantangan bagi peradaban Islam pada zaman kontemporer, karena ekses toleransi dan pluralisme akan merombak kemapanan dan memunculkan tatanan dan nilai-nilai baru semisal inklusivisme.

Tantangan selanjutnya pada masa kontemporer terhadap peradaban Islam lebih berupa transformasi budaya melalui kemajuan ilmu pengetahuan dan teknologi. Tanda-tanda ke arah

${ }^{26}$ Nurcholish Madjid, Nurcholish Madjid, "Mencari Akar-akar Islam bagi Pluralisme Modern Pengalaman Indonesia”, 99.

${ }^{27}$ Nurcholish Madjid, Nurcholish Madjid, "Mencari Akar-akar Islam bagi Pluralisme Modern Pengalaman Indonesia”, 99. 
itu jelas kelihatan, misalnya dalam proses globalisasi informasi dan nilai-nilai melalui produk kemajuan teknologi informasi mutakhir. Kemajuan teknologi seperti ini mendorong munculnya berbagai perubahan dan perkembangan nilai-nilai, norma-norma, dan gaya hidup baru di kalangan kaum muslim. ${ }^{28}$

Lambat laun nilai-nilai, norma-norma, dan gaya hidup baru yang dibawa oleh medium produk kemajuan teknologi itu akan memunculkan wabah budaya massa dan budaya pop dengan berbagai macam eksesnya. Budaya tandingan mungkin akan tumbuh pula dari lapisan tertentu kaum muslim sebagai respon terhadap budaya pop tersebut. Bila budaya tandingan tidak berdaya menghadapi budaya pop yang demikian kuat, akan mendorong terjadinya semacam kristalisasi dan radikalisasi kelompok-kelompok budaya tandingan yang sering berusaha mengubah keadaan secara radikal melalui penggunaan kekerasan.

Ada pendapat sebagian orang bahwa produk teknologi adalah bebas nilai. Namun kenyataan menunjukkan bahwa kehadiran suatu produk teknologi tidak hanya menghadirkan "bendanya", tetapi juga menghadirkan cara berfikir, pandangan hidup, norma, atau sistem nilai tertentu. Apalagi bila produk teknologi itu kemudian diberi muatan tertentu sesuai dengan budaya, nilai, atau norma produsen teknologi itu sendiri. Di sini prinsip Marshal Mc Luhan, ahli komunikasi tentang medium is the massage tetap relevan. Dalam konteks ini, dengan menggunakan kerangkan Johan Galtung, transformasi budaya nanti merupakan pelestarian budaya ilmu pengetahuan dan teknologi yang bersumber dari Barat. Melalui revolusi ilmu pengetahuan dan teknologi sejak abad ke 18 M., Barat umumnya tidak hanya tangguh di dibang militer dan politik, tetapi juga menjadi kekuatan budaya yang dominan. Didukung oleh keunggulan dalam berbagai aspek tadi, Barat melakukan ekspansi peradaban ke berbagai wilayah, termasuk

${ }_{28}$ Azyumardi Azra, Konteks Berteologi di Indonesia Pengalaman Islam, 196.

TAJDID Vol. 17, No. 1, Januari- Juni 2018 | 105 
kawasan muslim, yang tidak mempunyai kemampuan untuk membendung mereka. ${ }^{29}$

Menurut kerangka Johan Galtung selanjutnya, bahwa dalam proses akulturasi budaya dalam masyarakat dunia terdapat kesenjangan yang berakar pada struktur ekonomi yang pincang. Pada suatu pihak terdapat apa yang disebut sebagai "pusat", di lain pihak terdapat apa yang dinamakan sebagai "pinggiran". Sebagai pusat adalah negara-negara yang mempunyai kekuatan politik dan ekonomi, sementara sebagai pinggiran adalah negara-negara, karena kelemahan politik dan ekonomi, hampir tidak mempunyai kekuatan dan hak apa-apa. Dalam pola intraksi budaya kedua belah pihak ini, maka yang mempunyai ranking tertinggi itulah yang mendominasi bahkan memonopoli arus interaksi peradaban. $^{30}$

Dengan demikian, interaksi dan akulturasi budaya di antara kedua belah pihak ini berlangsung berat sebelah. Negara-negara yang merupakan pusat ekonomi, sekaligus juga merupakan pusat kebudayaan dan peradaban mendominasi masyarakat pinggiran secara ekonomi sekaligus pinggiran secara kebudayaan dan peradaban. Masyarakat pinggiran di sini mayoritas adalah kaum muslim. Dalam dinamika hubungan yang berat sebelah ini yang terjadi adalah destruksi budaya dan peradaban masyarakat pinggiran secara terarah dan sistematis. Jadi, merupakan destruksi terhadap budaya dan peradaban kaum muslim.

\section{Penutup}

Kemajuan pengetahuan dan teknologi mendorong Barat untuk mengadakan ekspansi ke wilayah-wilayah lain terutama ke kawasan berpenduduk kaum muslim. Peristiwa ini mengejutkan kaum muslim di kawasan dunia Islam karena Barat sebelumnya merupakan negara terkebelakang. Kemajuan Barat mencapai

29 Azyumardi Azra, Konteks Berteologi di Indonesia Pengalaman Islam, 196.

30 Azyumardi Azra, Konteks Berteologi di Indonesia Pengalaman Islam, 196.

106 | TAJDID Vol. 17, No. 1, Januari - Juni 2018 
lompatan jauh ke depan dengan berbagai macam hasil teknologi yang berujung pada modernitas. Kaum muslim tidak dapat berbuat banyak dalam mengejar ketertinggalan ini karena mereka sibuk menghadapi persoalan-persoalan internal misalnya kebodohan dan kemiskinan sehingga jarak antara antara kemajuan Barat dan ketertinggalan kaum muslim semakin hari semakin jauh.

Akhirnya modernitas di Barat berujung pada revolusi di bidang industri komunikasi dan informatika. Ini menciptakan kemudahan dalam kehidupan manusia sehingga terjadi globalisasi. Penduduk dunia yang luas dapat bersilaturrahmi dengan saudara atau sesamanya dengan mudah, tanpa didhalangi oleh jarak dan waktu. Dunia bagaikan "Desa Buana". Akibat dari itu semua adalah terjadinya transformasi budaya dan peradaban. Barat di satu sisi berada sebagai pusat, sementara wilayah kaum muslim pada sisi yang lain berada sebagai pinggiran. Mereka yang pinggiran harus menjadi konsumen bagi pusat yang produsen. Keadaan ini mendatangkan benturan bagi peradaban kaum muslim. Inti peradaban kaum muslim yang Islami sebenarnya sejalan dengan nilai modernitas dan globalisasi, namun karena keterputusan mata rantai intelektualitas, menyebabkan modernitas dan globalisasi berubah menjadi problem dan permasalahan bagi kaum muslim. Peradaban kaum muslim yang humanis digeser oleh arus peradaban Barat yang minimis.

\section{Daftar Pustaka}

Apter, David E., The Politics Of Modernization, (Chicago: The University Of Chicago Press, 1969).

Arkoun, "Introduction, Common etudier," dalam Pour une Critique de la Raison Islamique, (Paris: Maisonneuve et Larose, 1984).

------, "al-Islâm al-Mu'âshir," dalam al-Fiker al-Islâmy, Qirâ’ah Imiyyah, (Beirut: Markaz al-Inma' al-Qaumy, 1987).

------, "al-Harakah al-islâmiyyah," dalam Min Faisal al-Tafriqah ilâ Fasl al-Maqâl, Aina Hua al-Fiker al-Islâmy al-mu'âshir, terj. Hasyim Shalih, (Beirut: Dâr al-Saqy, 1993).

TAJDID vol. 17, No. 1, Januari - Juni 2018|107 
Azra, Azyumardi, Konteks Berteologi di Indonesia Pengalaman Islam, (Jakarta: Paramadina, 1999).

Bellah, Robert N., "Islamics Traditions and Problems Of Modernization," dalam Robert N. Bellah, ed., Beyond Belief, (New York: Harper \& Row, 1976).

Coser, Lewis A. dan Bernard Rosenberg, ed., Sociological Theory A Book OfReading, (London: The Macmillan Company, 1969).

/Cox, Harvey, Religion In The Secular City, (New York: Simon \& Schuster, 1984).

Huntington, Samuel P., Benturan Antar Peradaban dan Masa Depan Politik Dunia, terj. M. Sadar Islamil, (Yogyakarta: Qalam, 2002).

Madjid, Nurcholish, "Mencari Akar-akar Islam bagi Pluralisme Modern Pengalaman Indonesia," dalam Mark R. Woodward, Jalan Baru Islam Memetakan Paradigma Mutakhir Islam Indonesia, terj. Ihsan Ali Fauzi, (Bandung: Mizan, 1998).

------, Islam Doktrin dan Peradaban Sebuah Telaah Kritis tentang Masalab Keimanan Kemanusiaan dan Kemodernan, (Jakarta: Paramadina, 2000).

Poespowardojo, Soerhanto, Strategi Kebudayaan Suatu Pendekatan Filosofis, (Jakarta: Gramedia, 1989).

Russel, Bertrand, History Of Western Philosophy, (London: George Allen \& Unwin Ltd., 1974).

Toffler, Alvin, The Third Wave, (Toronto: Bantam Book Inc, 1984). Toynbee, Arnold, A Study Of History, ringk. DD. Somervelle, (Oxford: Oxford University Press, 1957).

Tylor, Edward B., Encyclopedia Americana, vol. 8, (New York: 1971). 